\title{
Functional Expression of the Gene $c u$, Encoding the Phytotoxic Hydrophobin Cerato-ulmin, Enables Ophiostoma quercus, a Nonpathogen on Elm, to Cause Symptoms of Dutch Elm Disease
}

\author{
Giovanni Del Sorbo, ${ }^{1}$ Felice Scala, ${ }^{1}$ Giuseppe Parrella, ${ }^{2}$ Matteo Lorito, ${ }^{1}$ Cecilia Comparini, ${ }^{2}$ \\ Michelina Ruocco, ${ }^{1}$ and Aniello Scala ${ }^{2}$ \\ 'Dipartimento ARBOPAVE, Sezione di Patologia Vegetale, Università di Napoli "Federico II", and CETE- \\ LOBI, 80055 Portici (NA) Italy; ${ }^{2}$ Istituto di Patologia e Zoologia Vegetale e Forestale, Università di \\ Firenze, 50144, Firenze, Italy \\ Accepted 28 September 1999.
}

\begin{abstract}
We studied the involvement of the phytotoxic hydrophobin cerato-ulmin $(\mathrm{CU})$ in pathogenesis and virulence of Dutch elm disease (DED) by expressing its encoding gene (cu) in Ophiostoma quercus, a nonpathogenic species on elm closely related to the DED pathogens $O$. ulmi and $O$. novoulmi. The production of the toxin was quantitatively determined in culture filtrates and in mycelial extracts of the transformants. Production of $\mathrm{CU}$ in vitro was associated with the ability to cause typical DED symptoms, consisting of foliar yellow and wilting and vascular tissue discoloration on a moderately resistant elm genotype. The presence of $\mathrm{CU}$ was monitored by enzyme-linked immunosorbent assay in symptomatic leaves of plants inoculated with $O$. quercus transformants expressing $\mathrm{CU}$ and found to be associated with wilt symptoms. In general, the virulence of the $c u$-expressing transformants, as measured in terms of vascular discoloration and percentage of defoliation, was lower than that of the mildly pathogenic isolate E2 of $O$. ulmi. However, one transformant (C39) displayed a virulence level intermediate between that of $\mathrm{E} 2$ and 182 , a highly virulent isolate of $O$. novo-ulmi. Our results indicate that $\mathrm{CU}$ production influences virulence in nonaggressive strains of Ophiostoma fungi.
\end{abstract}

Ophiostoma piceae (Münch) H. \& P. Syd. is a ubiquitous, weak, bark parasite of numerous tree species including conifers and hardwoods. It is often present on trees weakened by stress or disease and can also be isolated from bark beetles that breed in moribund trees. $O$. piceae is unable to colonize and cause disease symptoms on healthy plants. A species named $O$. roboris (Georgescu et al. 1948), later found to be co-specific with $O$. piceae (Brasier and Kirk 1989), is implicated in oak decline in Eastern Europe. In O. piceae, two intersterile populations, designated as $\mathrm{OPH}$ (Ophiostoma piceae hardwood) and OPC (Ophiostoma piceae conifers) groups,

Corresponding author: F. Scala; E-mail: scala@unina.it

The first, second, and seventh authors contributed equally to this work. have been described. The OPH group only attacks hardwood hosts, whereas OPC mainly attacks conifers but also attacks hardwoods. These two groups have different temperaturegrowth profiles (Brasier and Stephens 1993). Recent data (Pipe et al. 1995), based on randomly amplified polymorphic DNA (RAPD) analysis, confirmed a clear separation between the two groups, suggesting the reinstatement of the name Ophiostoma quercus (Georgevitch 1926) for the OPH group.

Cerato-ulmin (CU) is a $8-\mathrm{kDa}$, phytotoxic hydrophobin (Stringer and Timberlake 1993) produced in culture by the causal agents of Dutch elm disease (DED), O. ulmi and $O$. novo-ulmi, but not by the saprophyte $O$. quercus (named $O$. piceae in Scala et al. 1997b). CU displays the typical class II primary structure, sharing a conserved spacing between the cysteine residues involved in formation of four intramolecular loops with the other members of this class, namely cryparin from Cryphonectria parasitica, QID3 from Trichoderma harzianum, HFB1 and HFB2 from Trichoderma reesei, and cpa3 from Claviceps purpurea (Kershaw and Talbot 1997).

Like many other hydrophobins, $\mathrm{CU}$ is able to form unstable, rod-shaped aggregates at water-air interfaces and was found to be a component of the hyphal cell wall, as demonstrated by electron microscopy studies (Takai and Hiratsuka 1984) and by indirect immunofluorescence assay with anti-CU antibodies (Scala et al. 1997b). As a cell wall and hyphal surface component, CU plays a role in aerial hyphae formation and contributes to the overall hydrophobicity of hyphal surfaces. The occurrence of an unusual, flat-waxy colony lacking aerial mycelium in naturally occurring and laboratory-generated mutants of $O$. novo-ulmi unable to produce $\mathrm{CU}$ in culture was reported by Brasier et al. (1995) and by Tegli and Scala (1996), respectively. A similar phenotype was observed by Bowden et al. (1996) in mutants of a strong CU producer isolate of $O$. novo-ulmi in which the CU-encoding gene had been disrupted. An "easily wettable" colony phenotype was also observed in this mutant. A recent paper by the same research group (Temple et al. 1997) describes an increase in aerial hyphae formation in an $O$. ulmi isolate overexpressing $\mathrm{CU}$ after transformation with the gene $\mathrm{cu}$, encoding $\mathrm{CU}$ in $O$. novo- 
ulmi. The presence of a cell surface component cross-reacting with antibodies produced against CU was reported on hyphal cell walls of $O$. quercus (named $O$. piceae in Scala et al. 1997b).

Besides these functions and on the basis of a number of observations, CU has been invoked as one of the major factors in the pathogenesis of DED (Richards 1993). CU is abundantly secreted in planta during DED pathogenesis (Takai 1974) and it is detectable in symptomatic branches and leaves in amounts correlated to DED symptom severity (Scala et al. 1997a). Upon injection or absorption in plant tissues, homogeneous CU causes disease symptoms indistinguishable from those of DED and seems to be remarkably specific to elm. Previous studies (Richards 1993) have indicated the direct toxicity of $\mathrm{CU}$ to host plant cells and/or indirect damage due to its physico-chemical properties in the expression of DED symptoms. Furthermore, the production of CU in culture was found to be higher in the aggressive elm pathogen $O$. novoulmi than in the mildly pathogenic species O. ulmi (Brasier et al. 1990; Brasier 1991). In contrast to these results, more recent studies reported that $\mathrm{CU}$ has no function in virulence of DED pathogens. Natural (Brasier et al. 1995) or laboratory mutants of $O$. novo-ulmi obtained by either UV irradiation (Tegli and Scala 1996) or targeted $c u$ gene disruption (Bowden et al. 1996), which do not produce CU in culture, showed the same pathogenic ability as the $\mathrm{CU}$ producer isolates.

To further elucidate the actual involvement of CU in DED pathogenesis, we studied the pathogenicity of a number of transformants of $O$. quercus Georgevitch producing $\mathrm{CU}$ in culture. These transformants were obtained by transformation with the gene $c u$, encoding $\mathrm{CU}$ from a highly virulent isolate of $O$. novo-ulmi able to cause typical DED symptoms on elm plants. This indicates that $\mathrm{CU}$ production may contribute to the virulence of Ophiostoma fungi.

\section{RESULTS}

Generation of $\boldsymbol{O}$. quercus transformants producing $\mathrm{CU}$.

Co-transformation of plasmid pOHT, carrying a hygromycin resistance cassette and plasmid pCU-1, carrying the $\mathrm{cu}$ gene of isolate MH75 of O. novo-ulmi, generated hygromycinresistant transformants able to produce $\mathrm{CU}$ in liquid culture. Polymerase chain reaction (PCR) analysis of 50 randomly selected hygromycin-resistant transformant colonies, performed with two primers (hph-for and trpC-rev) that amplify a 1,237bp fragment in the hygromycin resistance cassette, indicated the presence of the hygromycin resistance cassette in all of them (not shown). No amplification product was obtained with DNA from the recipient isolate $\mathrm{H} 988$ of $O$. quercus or from the reference isolates 182 and $\mathrm{E} 2$ of $O$. novo-ulmi and $O$. $u l m i$, respectively. To check for the presence of the $c u$ gene introduced by transformation, we performed a PCR analysis of the transformants with the primers CU3 and CU4, designed on sequences specific for the $c u$ gene of $O$. novo-ulmi. These two primers did not give a product with DNA of the isolate H988 of $O$. quercus but yielded the predicted 778-bp fragment with DNA of the isolate 182 of O. novo-ulmi (Fig. 1A, lanes 1 and 2, respectively). The PCR analysis revealed the presence of the expected amplification product in 48 transformants, thus indicating that co-transformation had occurred in $96 \%$ of the 50 transformants tested. Figure 1 shows the patterns of a number of transformants, including $\mathrm{C} 15$ and $\mathrm{C} 20$ (which did not give an amplification product).

The production of CU in culture was quantitatively determined after culturing the 48 colonies in liquid Takai medium for 7 days. Considerable variation in extracellular CU production was observed and, on the basis of an arbitrary scale, transformants were grouped into strong (having a $\mathrm{CU}$ production index, [c.p.i.] > 250), medium $(50<$ c.p.i. $<250)$, and low or nil (c.p.i. < 50) producers. Eight transformants representative of the three classes $(\mathrm{C} 11$, representative of the strong producers; C14, C19, C31, C39, and C71, representative of the medium producers; and $\mathrm{C} 12$ and $\mathrm{C} 21$, representative of the low or nil producers) were chosen for further analyses. The amounts of extracellular CU produced by these isolates, as determined by the standard turbidimetric assay (Scala et al. 1994), are reported in Table 1 . None of the transformants produced more CU in culture than isolate 182. The culture filtrates of the parental isolate H988 as well as those of transformants I1 and I2, transformed only with pOHT, and not pCU-1, did not exhibit any turbidity. Enzyme-linked immunosorbent assay (ELISA) quantitative determination with anti$\mathrm{CU}$ antibodies revealed the presence of different amounts of $\mathrm{CU}$ in mycelial extracts of the transformants (Table 1). For some transformants (e.g., C11 and C31) we measured intracellular CU contents up to five times higher than that given by the O. novo-ulmi reference isolate 182 . A very low CU content was found in mycelium of transformant $\mathrm{C} 12$, which does not produce $\mathrm{CU}$ in liquid culture.

On solid MEA medium, no changes in colony color and morphology, development of aerial mycelium, or sporulation were

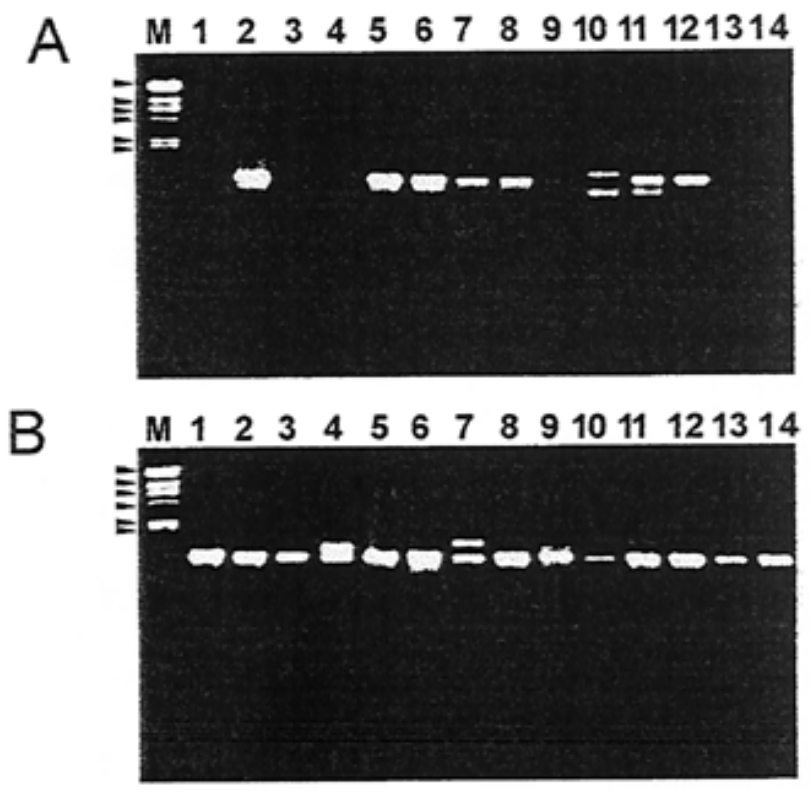

Fig. 1. Electrophoretic patterns of polymerase chain reaction (PCR) products obtained with primers CU3 and CU4, specific for the $c u$ gene, of DNA of Ophiostoma wild types and cu-transformed strains. A, Lane 1, O. quercus H988; lane 2, O. novo ulmi 182; lanes 3 and 4, transformants $\mathrm{I} 1$ and $\mathrm{I} 2$, respectively; lanes 5 to 13 , transformants $\mathrm{C} 10, \mathrm{C} 11$, C12, C14, C15, C16, C17, C19, C20, respectively; lane 14, control PCR in the absence of template DNA. B, Lane 1, O. novo ulmi 182; lanes 2 to 14, transformants C21, C22, C24, C27, C31, C33, C35, C39, C44, C47, C52, C71, C72, respectively. Lane M, $\lambda$ HindIII markers (23.1, 9.4, 6.5, $4.3,2.3,2.0 \mathrm{~kb}$, also indicated by arrows). 
observed in transformants expressing CU. No significant differences in daily radial growth rate at $23^{\circ} \mathrm{C}$ on MEA were detected between the parental strain $O$. quercus $\mathrm{H} 988$ and transformants (values ranging from $2.24 \pm 0.20$ to $2.65 \pm 0.41 \mathrm{~mm} \mathrm{day}^{-1}$ ).

After four cycles of growth on hygromycin-free, solid MEA containing $0.1 \mathrm{mg} \mathrm{ml}^{-1}$ of hygromycin, we could observe the loss of the hygromycin-resistant phenotype in about $5 \%$ of the transformants, when they were re-tested on MEA containing $0.1 \mathrm{mg} \mathrm{ml}^{-1}$ hygromycin. A slight reduction in $\mathrm{CU}$ production was observed in liquid cultures inoculated with mycelial plugs cut from plates subjected to five cycles of growth on solid MEA, with respect to primary transformants (data not shown). These two observations reveal a low but detectable instability of both hygromycin resistance and $\mathrm{CU}$ production in the transformants. No reduction in $\mathrm{CU}$ production was observed in $O$. novo-ulmi 182 and $O$. ulmi E2.

\section{Molecular characterization of $\boldsymbol{O}$. quercus transformants.}

Southern analysis of genomic DNA extracted from blastoconidia of the eight representative transformants, digested with XhoI, an enzyme that does not cut in either pOHT or pCU-1 plasmids, gave bands of high molecular weight $(30 \mathrm{~kb}$ or more) with all transformants when hybridized with a $\mathrm{cu}$ specific, 0.55-kb Pst I fragment from plasmid pCU-1 (not shown). This indicates the occurrence of single or tandem integrations of the plasmid pCU-1. The presence of a single, high-molecular-weight band in gel blot analysis performed with undigested DNA indicates a possible chromosomal integration of the transforming plasmid.

Digestion of DNA with HindIII, an enzyme that cuts once in both pOHT and pCU-1, gave complex hybridization pat-

Table 1. Growth and cerato-ulmin $(\mathrm{CU})$ production in liquid shake culture at $23^{\circ} \mathrm{C}$ by Ophiostoma wild types and $\mathrm{cu}$-transformed strains $(\mathrm{C} 11$ to $\mathrm{C} 71)^{\mathrm{t}}$

\begin{tabular}{|c|c|c|c|}
\hline Isolate & $\begin{array}{l}\text { Blastoconidia } \\
\mathrm{ml}^{-1}\left(\times 10^{8}\right)^{\mathbf{u}}\end{array}$ & $\begin{array}{l}\text { CU production } \\
\text { index of cul- } \\
\text { ture filtrates }\end{array}$ & $\begin{array}{l}\text { CU mycelial con- } \\
\text { tent (ng of CU mg }{ }^{-1} \\
\text { dry weight of } \\
\text { mycelium) }\end{array}$ \\
\hline \multicolumn{4}{|c|}{ Wild types } \\
\hline H988 & $5.8 \pm 1.7 \mathrm{a}$ & $0 \mathrm{a}$ & $0.51 \pm 0.08 \mathrm{a}$ \\
\hline $182^{\mathrm{x}}$ & $7.8 \pm 1.9 \mathrm{a}$ & $812 \pm 245 \mathrm{~d}$ & $18.02 \pm 1.90 \mathrm{e}$ \\
\hline$E 2^{y}$ & $9.3 \pm 3.3 \mathrm{a}$ & $2 \pm 2 \mathrm{a}$ & $8.83 \pm 1.15 b$ \\
\hline \multicolumn{4}{|c|}{ Transformants } \\
\hline $\mathrm{C} 11$ & $7.8 \pm 2.1 \mathrm{a}$ & $322 \pm 59 c$ & $88.52 \pm 8.20 c$ \\
\hline $\mathrm{C} 12$ & $4.3 \pm 1.9 \mathrm{a}$ & $2 \pm 1 \mathrm{a}$ & $0.70 \pm 0.09 \mathrm{a}$ \\
\hline $\mathrm{C} 14$ & $6.3 \pm 2.6 \mathrm{a}$ & $198 \pm 39 c$ & $9.20 \pm 0.92 b$ \\
\hline C19 & $5.3 \pm 2.2 \mathrm{a}$ & $183 \pm 13 b c$ & $2.33 \pm 0.28 \mathrm{ab}$ \\
\hline $\mathrm{C} 21$ & $5.3 \pm 2.2 \mathrm{a}$ & $16 \pm 8 \mathrm{ab}$ & $4.11 \pm 0.25 \mathrm{ab}$ \\
\hline $\mathrm{C} 31$ & $7.0 \pm 1.8 \mathrm{a}$ & $193 \pm 29 b c$ & $46.76 \pm 8.33 \mathrm{~d}$ \\
\hline C39 & $6.3 \pm 3.0 \mathrm{a}$ & $195 \pm 44 b c$ & $8.94 \pm 0.98 b$ \\
\hline C71 & $5.3 \pm 3.0 \mathrm{a}$ & $181 \pm 10 b c$ & $3.54 \pm 0.09 a b$ \\
\hline $\mathrm{I} 1^{\mathrm{z}}$ & $5.0 \pm 2.6 \mathrm{a}$ & $0 \mathrm{a}$ & $0.45 \pm 0.03 \mathrm{a}$ \\
\hline $\mathrm{I} 2^{\mathrm{z}}$ & $4.3 \pm 2.9 \mathrm{a}$ & $0 \mathrm{a}$ & $0.61 \pm 0.13 \mathrm{a}$ \\
\hline
\end{tabular}

${ }^{\mathrm{t}}$ Results are means \pm SD of four replicates; means in the column followed by the same letter do not differ significantly at $P=0.05$, according to the Tukey test.

u Initial concentration of blastoconidia was $5 \times 10^{5} \mathrm{ml}^{-1}$

${ }^{v} \mathrm{CU}$ production index (c.p.i.) of culture filtrates was calculated by a turbidimetric assay as described in Materials and Methods.

${ }^{\mathrm{w}} \mathrm{CU}$ mycelial contents were calculated by the quantitative enzymelinked immunosorbent assay as described in Materials and Methods.

${ }^{\mathrm{x}}$ Control strain of Ophiostoma novo-ulmi NAN race.

${ }^{\text {y }}$ Control strain of Ophiostoma ulmi.

${ }^{z}$ Control strain H988 transformed with the pOHT plasmid. terns in the various transformants (Fig. 2A). This demonstrates the occurrence of multiple and complex integration events followed by re-arrangements of the inserted sequences.

As reported for other species of filamentous fungi (Mellon and Casselton 1988), including O. ulmi (Royer et al. 1991) transformed with foreign genes, we could not find a correlation between the size, number, or intensity of hybridizing bands, and the levels of the encoded protein (in our case, CU) produced in liquid culture. This confirms that the site of integration rather than the number of integrated copies of the transformed gene plays a role in its expression level. The hybridization pattern of isolate 182 of $O$. novo-ulmi consisted of a single, 6.5-kb HindIII band (Fig. 2A, lane 12). The hybridization pattern given by isolate 182 upon digestion with $B g l \mathrm{II}$ gave a single, 1.9-kb band (data not shown), as reported in the literature for isolate MH75 (Bowden et al. 1994). In the parental isolate $\mathrm{H} 988$ of $O$. quercus and in control transformants I1 and I 2 there was a fainter but still clear hybridization of the probe with a single, 4.3-kb HindIII fragment, indicating the presence of a $\mathrm{cu}$-homolog in $O$. quercus (Fig. 2A, lanes 1, 10, and 11, respectively). The presence of a hybridizing band of the same size in some transformants (e.g., C12 and C21) suggests that disruption of the endogenous $\mathrm{cu}$-homolog by integration events in the mentioned $4.3-\mathrm{kb}$ fragment has not occurred. For the other transformants, the complexity of the pattern makes it difficult to draw conclusions regarding the disruption of the endogenous $c u$-homolog.

In Northern (RNA) analysis of total RNA isolated from 6day-old blastoconidia of transformants (Fig. 3), we obtained a single band with an approximate size of $0.75 \mathrm{~kb}$ with a $\mathrm{cu}$ specific, $0.55-\mathrm{kb}$ PstI fragment from plasmid pCU-1 as probe. The size of the hybridizing band corresponds to the predicted size of the mRNA encoding CU (Bowden et al. 1994). In some transformants we observed a correlation between the intensity of the bands displayed and the amount of CU produced in culture. In the CU strong producer transformant $\mathrm{C} 11$, the intensity of the band was much stronger than that displayed by all other transformants. No band was detected in the low or nil CU producers (C12 and C21), in O. quercus $\mathrm{H} 988$ or in the control transformants I1 and I2, whereas the medium CU producers (C14, C19, C31, C39, and C71) gave hybridizing bands of variable intensity.

\section{Effects of temperature on $\mathrm{CU}$ production in transformants.}

$O$. novo-ulmi and $O$. ulmi have different temperature optima for production of CU. In O. novo-ulmi, the maximum production of $\mathrm{CU}$ is observed at $23^{\circ} \mathrm{C}$, with a substantial decrease when the temperature is raised to $32^{\circ} \mathrm{C}$. In $O$. ulmi, CU production in culture at $32^{\circ} \mathrm{C}$ is higher than that observed at $23^{\circ} \mathrm{C}$ (Tegli et al. 1994). We studied the production of $\mathrm{CU}$ as a function of the growth temperature for transformants and wild-type strains (Table 2). After 7 days of culture, all fungi reached similar blastoconidia concentrations (about $5 \times 10^{8}$ ) at the four temperatures tested $\left(20,23,28\right.$, and $\left.32^{\circ} \mathrm{C}\right)$. We could observe, for most transformants, that the optimal temperature for $\mathrm{CU}$ production was $23^{\circ} \mathrm{C}$. An increase in temperature from 23 to $28^{\circ} \mathrm{C}$ determined a dramatic drop in $\mathrm{CU}$ production in all transformants tested. At $32^{\circ} \mathrm{C}$, no CU was detected in culture filtrates of all transformants. 
The effect of temperature was also determined on the mycelial content of $\mathrm{CU}$ in the transformants and wild types with anti-CU antibodies in a quantitative ELISA (Table 3). Only transformant $\mathrm{C} 31$ showed the highest $\mathrm{CU}$ content at $23^{\circ} \mathrm{C}$ as it occurred for the production of extracellular $\mathrm{CU}$, whereas in $\mathrm{C} 39$ the optimum was in the range 23 to $28^{\circ} \mathrm{C}$. In $O$. novoulmi 182, the optimal temperature for mycelial CU content was $28^{\circ} \mathrm{C}$. No statistically significant effect of temperature on mycelial $\mathrm{CU}$ content was observed in the wild types $O$. quercus $\mathrm{H} 988$ and $O$. ulmi $\mathrm{E} 2$ and in transformants C12, C14, and C71 (Table 3).

\section{Pathogenicity tests.}

Transformants of $O$. quercus producing CU in liquid culture were able to cause disease symptoms identical to those of DED on elm, consisting of xylem discoloration, leaf chlorosis, defoliation, and shoot wilt, 28 days after inoculation (Fig. 4). The percentages of foliar symptoms and vas-

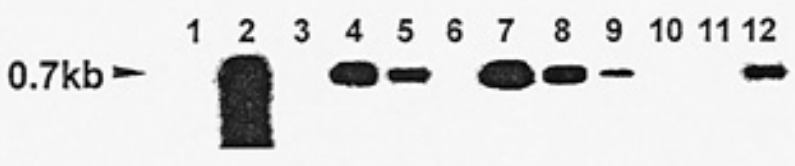 ............}

Fig. 3. Northern (RNA) blot analysis of $c u$ gene expression. A digoxigenin-labeled, $0.55-\mathrm{kb}$ Pst I fragment of plasmid $\mathrm{pCU}-1$, containing part of the $\mathrm{cu}$ gene of Ophiostoma novo-ulmi MH75 was used as a probe. Lane 1, O. quercus H988; lanes 2 to 9: transformants C11, C12, C14, C19, C21, C31, C39, C71, respectively; lanes 10 and 11, control transformants I1 and I2; lane 12, O. novo-ulmi 182 . To check for equal loading of the slots, actin controls probed with a digoxigenin-labeled, $0.7-\mathrm{kb}$ fragment of the BcactA gene of Botrytis cinerea are shown below.
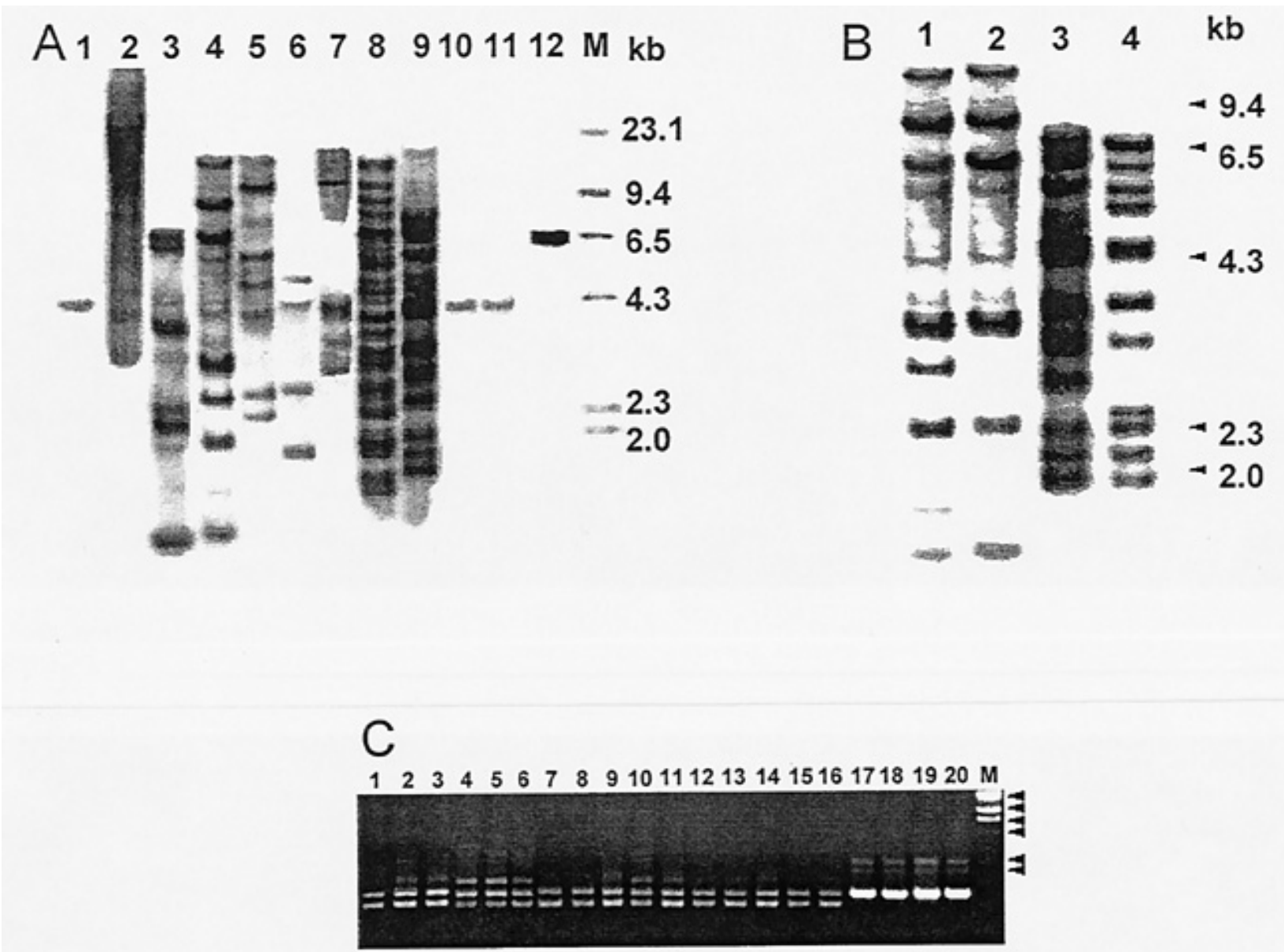

Fig. 2. Molecular characterization of HindIII-digested DNA (10 $\mu \mathrm{g}$ per lane) from Ophiostoma wild types and $c u$-transformed strains. A, Southern blot analysis. Blot was probed with a digoxigenin-labeled, $0.55-\mathrm{kb}$ Pst I fragment of plasmid pCU-1 containing part of the cu gene of $O$. novo-ulmi MH75. Lane 1, O. quercus H988; lanes 2 to 9, transformants C11, C12, C14, C19, C21, C31, C39, and C71, respectively; lanes 10 and 11, control transformants I1 and I2; lane 12, O. novo-ulmi 182; lane M, digoxigenin-labeled $\lambda$ HindIII markers. B, Southern blot analysis of HindIII-digested DNA from transformants C14 and C71, used in pathogenicity trials, (lanes 1 and 3, respectively) and reisolated from a tree inoculated with this isolate (lanes 2 and 4, respectively), with the same probe as in A. C, Random amplified polymorphism DNA (RAPD) analysis with primer 220 (see Materials and Methods) of DNA from Ophiostoma wild types and $c u$-transformed strains prepared from cultures used for pathogenicity trials and reisolated from artificially inoculated elm trees. Lane 1, O. quercus $\mathrm{H} 988$; lanes 2 to 8, transformants C11, C12, C19, C21, C31, C39, and C71, respectively, before plant inoculation; lanes 9 to 15, DNA obtained from reisolated transformants C11, C12, C19, C21, C31, C39, and C71, respectively; lane 16, control transformant I1, lane 17, O. novo-ulmi 182; lane 18, O. novo-ulmi $\mathrm{H} 328$; lane 19, O. ulmi E2; lane 20, O. ulmi Yu99; lane M, $\lambda$ HindIII markers. 
cular browning were assumed to be key parameters for evaluation of disease severity (Fig. 5). Recipient strain $O$. quercus $\mathrm{H} 988$ did not produce any leaf chlorosis or defoliation on inoculated elm plants. However, it caused a slight vascular discoloration around the inoculation site, which extended about $25 \mathrm{~cm}$ in length. Control transformants I1 and $\mathrm{I} 2$, as well as transformant $\mathrm{C} 12$, a nil CU producer, behaved in the same way as H988. Compared with the wildtype H988, transformants $\mathrm{C} 11$ and $\mathrm{C} 14$ caused more extended and intense vascular discoloration. Transformants C21, C31, and C71 caused wilting on about 5\% of leaves, while discoloration length was comparable to that of the wild-type H988. Much higher percentages of foliar symptoms were caused by the other two transformants, C19 (12\% defoliation) and C39 (50\% defoliation). C39 also caused very extended and intense vascular xylematic discoloration. The reference isolates $O$. novo-ulmi 182 and $O$. ulmi E2 caused symptoms (including both chlorosis and wilt) on 90 and $16 \%$ of leaves, respectively. Both strains produced extended vascular symptoms, with intense browning.

Samples of symptomatic leaves of plants inoculated with transformants C19, C21, C31, C39, and C71, as well as of leaves of plants inoculated with strains 182 and E2, analyzed by ELISA, revealed the presence of CU, at levels in the range $2.11 \pm 0.75$ (transformant C31) and $3.88 \pm 0.97$ (transformant C39) $\mathrm{ng} \mathrm{mg}^{-1}$ dry weight tissue. These values are similar to those reported for symptomatic leaves present on plants expressing DED symptoms, which are $3.45 \pm 1.04$ and $7.48 \pm$ $3.87 \mathrm{ng} \mathrm{mg}^{-1}$ dry weight tissue in samples collected at day 34 after inoculation for plants inoculated with $O$. ulmi E2 and $O$. novo-ulmi H328, respectively (Scala et al. 1997a). No CU was detected in leaves of plants mock-inoculated with water or in asymptomatic leaves of plants inoculated with Ophiostoma wild types and $O$. quercus transformants.

Twenty-eight days after inoculation, attempts to reisolate the transformants and reference wild-type isolates were made at the circular section of the plant corresponding to the inoculation site and in sections cut $60 \mathrm{~cm}$ above and below it. For each strain, reisolation was attempted from 100 frag-

Table 2. Effect of temperature on extracellular cerato-ulmin production by Ophiostoma wild types and $\mathrm{cu}$-transformed strains (C12 to C71)

\begin{tabular}{lcccc}
\hline & \multicolumn{4}{c}{ Cerato-ulmin production index of culture filtrates } \\
\cline { 2 - 5 } Isolate $^{\mathbf{v}, \mathbf{w}}$ & $\mathbf{2 0}^{\circ} \mathbf{C}$ & $\mathbf{2 3}^{\circ} \mathbf{C}$ & $\mathbf{2 8}^{\circ} \mathbf{C}$ & $\mathbf{3 2}^{\circ} \mathbf{C}$ \\
\hline Wild types & & & & \\
H988 & $0 \mathrm{a}$ & $0 \mathrm{a}$ & $0 \mathrm{a}$ & $0 \mathrm{a}$ \\
$182^{\mathrm{y}}$ & $279 \pm 21 \mathrm{a}$ & $812 \pm 122 \mathrm{~b}$ & $233 \pm 22 \mathrm{a}$ & $83 \pm 14 \mathrm{a}$ \\
E2 $^{\mathrm{z}}$ & $0 \mathrm{a}$ & $2 \pm 1 \mathrm{a}$ & $42 \pm 11 \mathrm{a}$ & $193 \pm 25 \mathrm{~b}$ \\
Transformants & & & & \\
C12 & $0 \mathrm{a}$ & $2 \pm 1 \mathrm{a}$ & $0 \mathrm{a}$ & $0 \mathrm{a}$ \\
C14 & $179 \pm 31 \mathrm{~b}$ & $198 \pm 19 \mathrm{~b}$ & $15 \pm 6 \mathrm{a}$ & $0 \mathrm{a}$ \\
C31 & $115 \pm 18 \mathrm{~b}$ & $193 \pm 14 \mathrm{c}$ & $9 \pm 4 \mathrm{a}$ & $0 \mathrm{a}$ \\
C39 & $162 \pm 12 \mathrm{~b}$ & $195 \pm 22 \mathrm{~b}$ & $23 \pm 12 \mathrm{a}$ & $0 \mathrm{a}$ \\
C71 & $137 \pm 71 \mathrm{ab}$ & $181 \pm 5 \mathrm{~b}$ & $40 \pm 28 \mathrm{ab}$ & $0 \mathrm{a}$ \\
\hline
\end{tabular}

${ }^{\mathrm{u}}$ Initial concentration of blastoconidia was $5 \times 10^{5} \mathrm{ml}^{-1}$.

${ }^{\mathrm{v}}$ Calculated as cerato-ulmin production index of culture filtrates (see Materials and Methods).

${ }^{\mathrm{w}}$ Results are means \pm SEM of four replicates; means in the row followed by the same letter do not differ significantly at $P=0.05$, according to the Tukey test.

${ }^{x}$ Control strain of Ophiostoma quercus.

${ }^{y}$ Control strain of Ophiostoma novo-ulmi NAN race.

${ }^{\text {z }}$ Control strain of Ophiostoma ulmi. ments of xylematic tissue at each section. In $57 \%$ of cases, strain $\mathrm{H} 988$ of $O$. quercus was reisolated at the inoculation point. This strain could be reisolated in $20 \%$ of cases at the lower section and in $0 \%$ of cases at the upper section. At the lower section and at the inoculation point, reisolation frequencies of transformants were not significantly different from those of H988 (data not shown). We did not reisolate any of the transformants at the upper section, with the exceptions of C31 and C39, which could be reisolated in 6 and $71 \%$ of cases, respectively. Reference strain 182 was reisolated at high frequencies in all three sections $(77 \%$ at the upper section, $100 \%$ at the inoculation point, and $93 \%$ at the lower section. For strain E2, the percentages of reisolation were 80,96 , and $26 \%$, respectively, at the upper section, inoculation point, and lower section.

The phenotype of all reisolated transformants was tested by plating them on hygromycin-amended MEA medium. In about $90 \%$ of cases the hygromycin-resistant phenotype was conserved and the PCR with the two primers designed on the hygromycin resistance cassettes displayed the expected 1,237-bp band. In $10 \%$ of cases in which the hygromycin resistance phenotype was lost no band was observed with specific primers. For each strain, DNA was extracted from three randomly chosen reisolated colonies, digested with HindIII, and analyzed by Southern blot with the $0.55-\mathrm{kb}$ Pst I fragment of plasmid pCU-1. Hybridization patterns of reisolated fungi were identical to those displayed by HindIIIdigested DNA prepared from the same fungi before inoculation. In two cases, however, we could observe small changes in the number and molecular weight of the $c u$-probe hybridizing bands (Fig. 2B). These data indicate the occurrence of some re-arrangements of the tandem co-integrates of the $c u$ gene during the pathogenesis. The identity of reisolated fungi was also checked by RAPD analysis with primer 220, which allows clear discrimination between the amplification pattern of O. quercus H988 (Fig. 2C, lane 1) and those of $O$. novo-ulmi 182 and $\mathrm{H} 328$ or $O$. ulmi E2 and Yu99 (Fig. 2C, lanes 17-20). For each transformant, we ob-

Table 3. Effect of temperature on mycelial content of cerato-ulmin (CU) in Ophiostoma wild types and $\mathrm{cu}$-transformed strains (C12 to C71)

\begin{tabular}{|c|c|c|c|c|}
\hline \multirow[b]{2}{*}{ Isolate $^{\mathrm{u}}$} & \multicolumn{4}{|c|}{ CU mycelial content ${ }^{\mathrm{v}, \mathrm{w}}$} \\
\hline & $20^{\circ} \mathrm{C}$ & $23^{\circ} \mathrm{C}$ & $28^{\circ} \mathrm{C}$ & $32^{\circ} \mathrm{C}$ \\
\hline \multicolumn{5}{|c|}{ Wild types } \\
\hline $\mathrm{H} 988^{\mathrm{x}}$ & $0.66 \pm 0.11 \mathrm{a}$ & $0.51 \pm 0.04 \mathrm{a}$ & $0.71 \pm 0.13 \mathrm{a}$ & $1.60 \pm 0.76 \mathrm{a}$ \\
\hline $182^{y}$ & $3.21 \pm 0.98 \mathrm{a}$ & $18.02 \pm 0.95 \mathrm{a}$ & $51.27 \pm 7.90 b$ & $13.52 \pm 9.67 \mathrm{a}$ \\
\hline$E 2^{z}$ & $5.12 \pm 3.49 \mathrm{a}$ & $8.83 \pm 0.57 \mathrm{a}$ & $8.55 \pm 3.85 \mathrm{a}$ & $7.82 \pm 4.27 \mathrm{a}$ \\
\hline \multicolumn{5}{|c|}{ Transformants } \\
\hline $\mathrm{C} 12$ & $0.29 \pm 0.11 \mathrm{a}$ & $0.70 \pm 0.04 \mathrm{a}$ & $0.49 \pm 0.24 \mathrm{a}$ & $2.92 \pm 1.44 \mathrm{a}$ \\
\hline $\mathrm{C} 14$ & $5.16 \pm 4.18 \mathrm{a}$ & $9.20 \pm 0.46 \mathrm{a}$ & $10.56 \pm 2.16 \mathrm{a}$ & $2.00 \pm 1.42 \mathrm{a}$ \\
\hline C31 & $1.11 \pm 0.59 \mathrm{a}$ & $46.76 \pm 4.16 c$ & $25.09 \pm 3.76 b$ & $2.90 \pm 0.15 \mathrm{a}$ \\
\hline C39 & $4.21 \pm 0.85 \mathrm{a}$ & $8.49 \pm 0.49 b$ & $11.31 \pm 1.56 b$ & $1.56 \pm 0.38 \mathrm{a}$ \\
\hline C71 & $3.20 \pm 1.10 \mathrm{a}$ & $3.54 \pm 0.40 \mathrm{a}$ & $4.35 \pm 1.21 \mathrm{a}$ & $4.92 \pm 3.67 \mathrm{a}$ \\
\hline \multicolumn{5}{|c|}{$\begin{array}{l}\text { u Initial concentration of blastoconidia was } 5 \times 10^{5} \mathrm{ml}^{-1} \text {. } \\
\mathrm{v}^{\mathrm{v}} \text { Calculated as ng CU mg } \mathrm{m}^{-1} \text { dry weight of mycelium with anti-CU anti- } \\
\text { bodies in a quantitative enzyme-linked immunosorbent assay (see } \\
\text { Materials and Methods). }\end{array}$} \\
\hline \multicolumn{5}{|c|}{$\begin{array}{l}\text { w Results are means } \pm \text { SEM of four replicates; means in the row followed } \\
\text { by the same letter do not differ significantly at } \mathrm{P}=0.05 \text {, according to } \\
\text { the Tukey test. }\end{array}$} \\
\hline \multicolumn{5}{|c|}{${ }^{x}$ Control strain of Ophiostoma quercus. } \\
\hline \multicolumn{5}{|c|}{$\begin{array}{l}\text { y Control strain of Ophiostoma novo-ulmi NAN race. } \\
\text { z Control strain of Ophiostoma ulmi. }\end{array}$} \\
\hline
\end{tabular}


served corresponding RAPD patterns of DNA extracted after the reisolation with those obtained using DNA extracted from the cultures used for the inoculation (Fig. 2C). Results from Southern and RAPD analyses should exclude the possibility of cross contaminations either from within the experiment or from the outside.

\section{DISCUSSION}

The role of CU in expression of DED symptoms has been the object of a number of studies during the last two decades. Early evidence reported by Takai $(1974,1980)$ and Richards
(1993) assigned a pivotal role to CU in DED symptoms. Purified CU was found to reproduce the same syndrome and morpho-physiological alterations of DED, consisting of wilting, reduction in transpiration, increase in leaf respiration rate, and electrolyte loss (Takai 1974; Takai and Hiratsuka 1984). It was found that the amount of toxin produced in culture correlated to disease severity caused by the aggressive species $O$. novo-ulmi and the nonaggressive species O. ulmi, and Brasier (1991) used CU production as a major parameter to distinguish between the DED pathogens.

Recent studies have suggested that $\mathrm{CU}$ has only a marginal role as a wilt toxin in DED pathogenesis. Brasier et al. (1995)

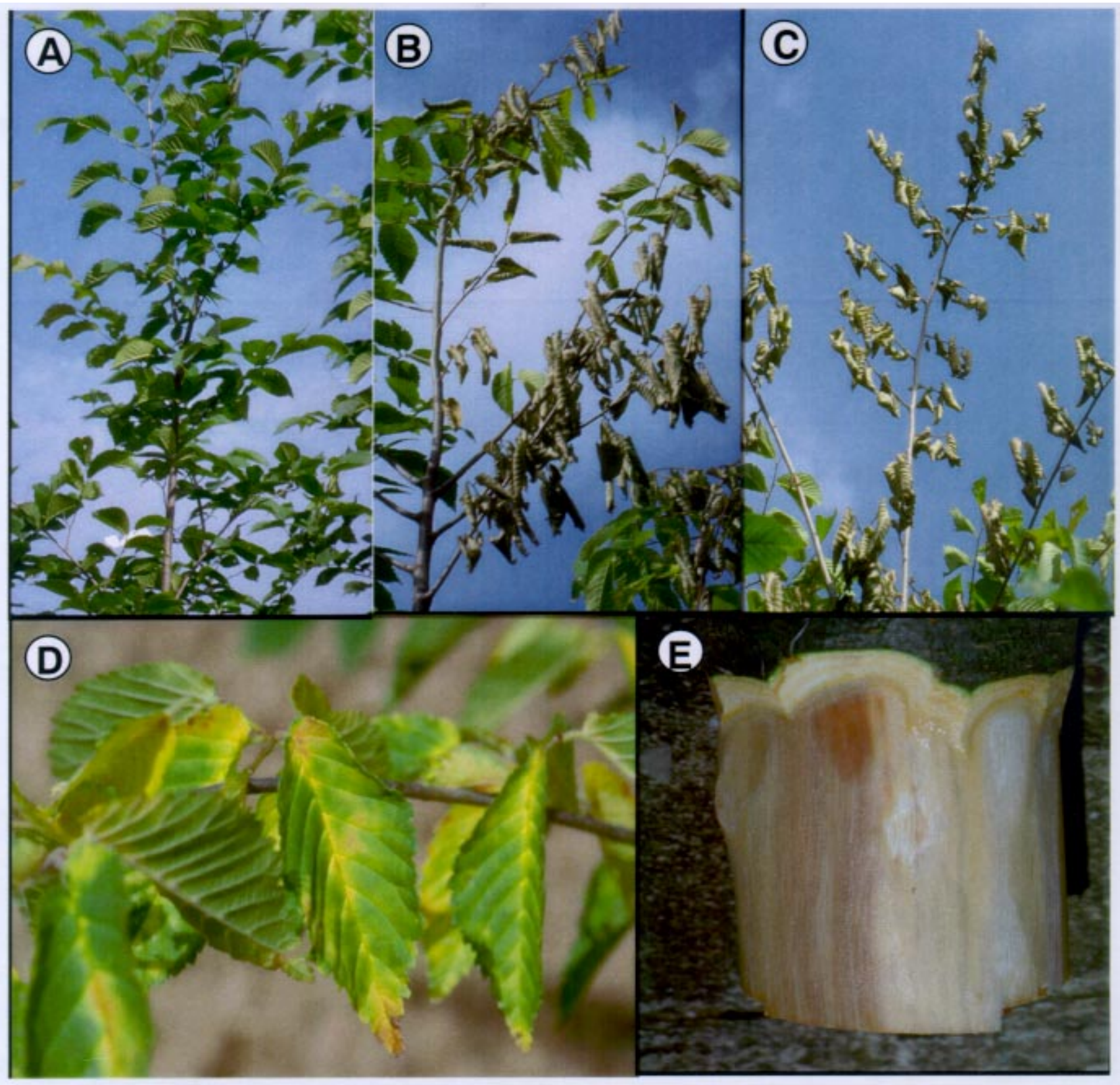

Fig. 4. Dutch elm disease symptoms caused by Ophiostoma wild types and $O$. quercus transformants expressing the $c u$ gene of $O$. novo-ulmi 28 days after inoculation. A, Control plant, inoculated with O. quercus H988. B, Foliar wilt symptoms caused by O. novo-ulmi 182. C, Foliar wilt caused by transformant C39. D, Foliar yellow symptoms caused by transformant C39. E, Vascular tissues browning in plants displaying foliar symptoms after inoculation with transformant C39. 
described natural isolates of $O$. novo-ulmi (NAN race) that were not able to produce $\mathrm{CU}$ in culture but retained a normal pathogenic ability on both susceptible and moderately resistant elm genotypes. In addition, spontaneous, laboratorygenerated mutants of $O$. novo-ulmi that failed to produce $\mathrm{CU}$ in culture caused disease symptoms on susceptible and partially resistant elm genotypes that were not significantly different from those of the CU producer parental isolate $\mathrm{H} 328$ (Tegli and Scala 1996). Further, Bowden et al. (1996) generated a mutant selectively disrupted in the $\mathrm{CU}$-encoding gene of a highly virulent isolate (VA 30) of O. novo-ulmi. The disruptant was unable to synthesize $c u$-encoded mRNA and to produce $\mathrm{CU}$ in culture. Analysis of the virulence of the transformant was carried out on extremely susceptible elm genotypes by measuring vascular discoloration and foliar wilting. The results (Bowden et al. 1996) indicated that there were no significant differences between the virulence of the $\mathrm{CU}^{-}$mu-
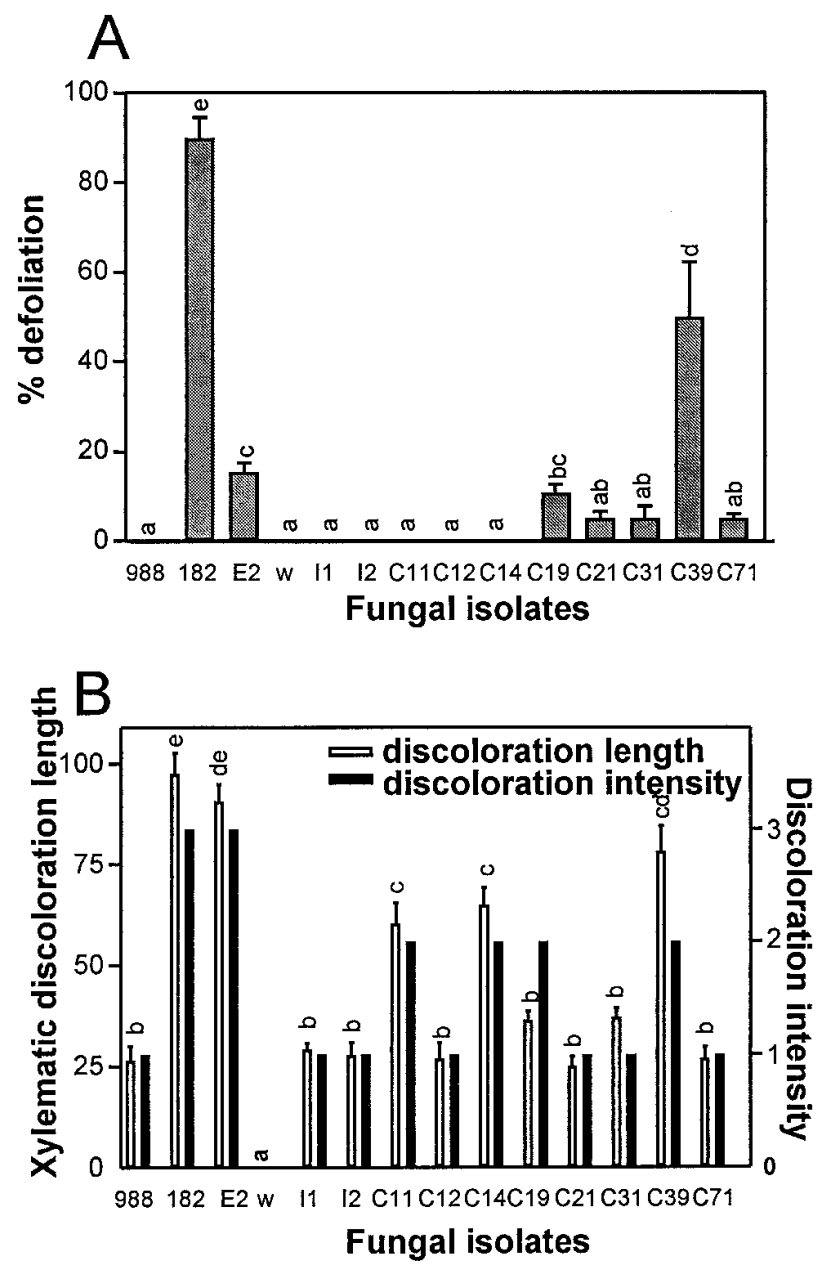

Fig. 5. Symptom severity caused by Ophiostoma quercus H988, O. novo-ulmi 182, O. ulmi E2, water (= w), control transformants I1 and I2, and $c u$-transformed strains C11, C12, C14, C19, C21, C31, C39, and C71. Each strain was inoculated on five plants. Different letters indicate values significantly different at $P=0.05$, according to the Tukey test. A, Foliar symptoms severity expressed as percentage of defoliation (including defoliation, wilt, and chlorosis) B, Vascular discoloration length (in $\mathrm{cm}$ ) and intensity (on a $0-3$ arbitrary scale with $0=$ no discoloration, $3=$ intense discoloration). tant and that of the parental VA30 aggressive isolate. On the basis of these data, the authors concluded that $\mathrm{CU}$ is not a primary virulence determinant of $O$. novo-ulmi. Another study from the same group demonstrated that the stable integration and expression of the $\mathrm{cu}$ gene of $O$. novo-ulmi in a nonaggressive isolate of $O$. ulmi strongly increased the amount of $\mathrm{cu}$ transcript and $\mathrm{CU}$ in culture to levels similar to those of the donor isolate of $\mathrm{O}$. novo-ulmi. However, the increase in $\mathrm{CU}$ production did not cause any increase in virulence on seedlings of $U$. americana (Temple et al. 1997). By analyzing a number of parameters, such as colony morphology, blastoconidia adhesion properties, and resistance to stress conditions, the authors concluded that, besides its fundamental role in morphogenesis, $\mathrm{CU}$ is an important parasitic fitness factor that enhances hydrophobic properties of the cell surface, thus favoring adhesion to vector bark beetles and protecting the fungus from desiccation (Temple et al. 1997). Moreover, CU could act as a fitness factor in planta, possibly by protecting the fungus from the plant defense response (Temple et al. 1997). An involvement of $\mathrm{CU}$ in the resistance to mansonones, the elm phytoalexins, has been hypothesized (Wu et al. 1989). In this view, the production of CU confers to the fungus a selective advantage and favors its aggressiveness, which results in the ability to quickly colonize and debilitate plants.

In the present work, we tried to clarify the role of $\mathrm{CU}$ in DED by a different approach, based on the expression of the $c u$ gene from $O$. novo-ulmi in $O$. quercus, a nonpathogen of elm, and analyzed the effects of this transformation on virulence.

For a number of reasons, O. quercus H988 represents a suitable recipient for studying the effect of the expression of the $c u$ gene. Many isolates of this species, including H988, an isolate from elm, are able to survive in elm plants for several weeks without causing any disease symptoms (Sutherland et al. 1995). O. quercus shares many similarities of both its teleomorph and anamorph with the DED pathogens. Furthermore, conidia of $O$. quercus of the appropriate compatibility type induce the development of mature perithecia in both $O$. novo-ulmi and $O$. ulmi. However, these perithecia were never found to contain viable ascospores, indicating the occurrence of a reproductive barrier at the pre-zygotic stage between the two species (Brasier 1993). Gene flow from O. quercus or closely related species to a nonaggressive isolate of $O$. ulmi has been proposed to generate the highly aggressive isolates of O. novo-ulmi (Brasier 1990; Charter et al. 1996). Strong correlations between $O$. quercus and DED pathogens were found by comparing partial sequences of ribosomal DNA (Hausner et al. 1993). Another common feature is the presence of a protein immunologically related to $\mathrm{CU}$ in mycelial extracts and on blastoconidia surface, but not in culture filtrate of O. quercus (Scala et al. 1997b). Data collected in the present work indicate the presence in $O$. quercus $\mathrm{H} 988$ of a sequence cross-hybridizing with the $\mathrm{cu}$ fragment used as a probe in Southern analysis (Fig. 2A). Cloning and sequencing of the $O$. quercus gene putatively encoding the $\mathrm{CU}$ homologue protein cross-reacting with anti-CU antiserum is currently in progress.

Our results demonstrate that the expression of the $c u$ gene of $O$. novo-ulmi in $O$. quercus $\mathrm{H} 988$ confers the ability to produce $\mathrm{CU}$ in culture and to cause DED symptoms. All CU- 
producing transformants caused an increase in severity of vascular and/or foliar symptoms, the two parameters commonly considered for the evaluation of virulence of DED pathogens (Smalley and Guries 1993; Sutherland et al. 1997). For the most virulent of our transformants, C39, the severity of foliar symptoms was much higher than that of the moderately virulent isolate $O$. ulmi $\mathrm{E} 2$, and about one half that of the highly virulent isolate of $O$. novo-ulmi 182. In comparison with the wild-type $O$. quercus $\mathrm{H} 988$, we also observed an increase in reisolation frequency of two transformants (C31 and especially C39) in stem sections distant from the inoculation point, indicating an improvement in colonizing ability as a consequence of the acquisition of pathogenicity. Analysis of the pathogenicity on elm of eight transformants that produce different levels of $\mathrm{CU}$ indicates that this hydrophobin may function as a virulence factor when introduced into $O$. quercus. This conclusion is supported by the fact that leaves from plants inoculated with transformants displayed typical DED symptoms and contained amounts of the toxin similar to those determined in leaves of plants inoculated with DED pathogens.

However, we could establish that the quantitative production of CU in culture was partially correlated with disease severity. For example, C11, the highest $\mathrm{CU}$ producer, caused only an increase in vascular symptoms compared with H988, whereas C39, a medium CU producer, determined a more extended vascular discoloration and severe defoliation. In relation to this aspect it should be pointed out that transformants may produce in planta amounts of $\mathrm{CU}$ that do not correlate with the amounts produced in culture. In addition, transformants showed some degrees of instability in the levels of CU production. The reasons for the instability may reside in the fact that our transformants contain several copies of a foreign dominant gene, which likely undergo a genetic re-arrangement (Fig. 2B). This phenomenon may occur especially when transformants are transferred from artificial medium to plant tissues.

We cannot exclude the possibility that the positive influence of $c u$ on the pathogenicity of $O$. quercus could derive, at least in part, from the interaction with other genes. This possibility could be verified by following the segregation of the $c u$ gene relative to virulence. The recent work of Et-Touil et al. (1999) shows that a locus designated Pat1 has a fundamental role in virulence of $O$. novo-ulmi. An allelic variant of this gene could have been introgressed from $O$. ulmi and determined a low level of aggressiveness. In this case, the production of relatively high amounts of $\mathrm{CU}$ did not seem to affect virulence.

In the study of Temple et al. (1997), one single copy of the $c u$ gene was sufficient to determine in $O$. ulmi a marked increase in $\mathrm{cu}$ transcript. This resulted in an increase in CU production in culture filtrate to a level similar to that of the high $\mathrm{CU}$ producer $O$. novo-ulmi VA30, which, however, made at least 20 times less $c u$ transcript than the $O$. ulmi transformant. Similarly, in some of our transformants (e.g., C11 and C31) we detected amounts of $c u$ transcript and intracellular contents of CU much higher than those found in O. novo-ulmi 182, which produces more $\mathrm{CU}$ in culture than all transformants. These observations suggest that the production of CU seems to be under different control mechanisms in $O$. novo-ulmi than in $O$. ulmi and O. quercus.

In a previous study, the influence of temperature on $\mathrm{CU}$ production in pathogenic and nonpathogenic Ophiostoma spp. was investigated (Scala et al 1997b). In liquid culture, all spe- cies reached the stationary phase after 4 days of growth, attaining similar blastoconidia concentrations at both 23 and $32^{\circ} \mathrm{C}$. In $O$. novo-ulmi, growth at $32^{\circ} \mathrm{C}$ did not have negative effects on cellular CU content but severely reduced extracellular CU production. Our data indicate that extracellular CU production of all transformants is temperature dependent, with a pattern similar to that of O. novo-ulmi, and that their growth rates are similar at all temperatures tested. At the moment, the molecular mechanisms by which temperature influences $\mathrm{CU}$ production dependent are not known. More investigations are needed to study the effect of the temperature on the promoter of the $c u$ gene, on the mRNA or protein stability, and on $\mathrm{CU}$ secretion.

In light of our results and those reported in the literature, we conclude that, in addition to the host plant genotype, methods of inoculation, and environmental conditions used in pathogenicity tests, the genetic background where the $c u$ gene is expressed influences the contribution of $\mathrm{CU}$ to the virulence of Ophiostoma spp. The present study provides evidence supporting the hypothesis envisaged by Brasier $(1990,1995)$ of the potential risk that an $O$. quercus-like fungus might acquire the $c u$ gene from $O$. novo-ulmi and become a severe pathogen of oak. For these reasons, experiments with strains in which pathogenicity has been genetically modified need to be performed with extreme care, following safety measures such as those adopted in this work.

\section{MATERIALS AND METHODS}

\section{Fungal strains and culture conditions.}

O. quercus strain H988 was isolated in 1986 in Tagikistan from elm and its inability to produce $\mathrm{CU}$ is reported in Scala et al. (1997b). The origins and levels of CU production of reference isolates of O. novo-ulmi 182 and $\mathrm{H} 328$ (O. ulmi aggressive) and $O$. ulmi $\mathrm{E} 2$ and Yu99 (O. ulmi nonaggressive) are described elsewhere (Scala et al. 1997b). Fungi were routinely cultivated on malt extract agar Oxoid (MEA) (Brasier 1981) or in liquid Takai medium (Takai 1978). For long-term storage, blastoconidia collected from 3-day-old liquid shaken minicultures $(3 \mathrm{ml})$ in Takai medium were resuspended in $10 \%$ (vol/vol) glycerol and stored at $-70^{\circ} \mathrm{C}$. Yeastlike blastoconidia multiplication in liquid culture and mycelial radial growth on MEA were determined according to methods reported by Tegli and Scala (1996) and expressed as blastoconidia concentration (units $\mathrm{ml}^{-1}$ ) and daily radial growth (mm day $\left.^{-1}\right)$, respectively.

\section{Plasmids.}

Plasmid pCU-1, which contains a 1.9-kb BglII fragment consisting of the coding sequence of the $\mathrm{cu}$ gene of $\mathrm{O}$. novoulmi strain MH75 (a NAN isolate) preceded by 434 bases of its promoter and followed by 1,014 bases of terminator sequence (Bowden et al. 1994), was kindly provided by P. Horgen. Plasmid pOHT, containing the hygromycin resistance gene $h p h$ of Escherichia coli under the control of the promoter of the gene oliC of Aspergillus nidulans, is described in ten Have et al. (1998).

\section{Transformation of $O$. quercus.}

Protoplasts of $O$. quercus strain H988 were prepared from blastoconidia obtained from 500-ml liquid shaken cultures in 
Takai medium, and polyethylene glycol (PEG)-mediated transformation was performed according to the second procedure described by Royer et al. (1991). Approximately $2 \times 10^{7}$ protoplasts were suspended in $600 \mu$ of STC (1 M sorbitol, 25 $\mathrm{mM}$ Tris- $\mathrm{HCl} \mathrm{pH} 7.5,50 \mathrm{mM} \mathrm{CaCl} 2$ ) and incubated with 0.5 $\mu \mathrm{g}$ of HindIII-linearized pOHT plasmid and $5 \mu \mathrm{g}$ of HindIII linearized pCU-1. As controls, aliquots of protoplasts were also transformed with either plasmid alone. After dilution with complete medium (CM; Royer et al. 1991) and $2 \mathrm{~h}$ of incubation at room temperature, aliquots of $3 \times 10^{5}$ protoplasts in $100 \mu \mathrm{l}$ were spread on solid CM containing $0.1 \mathrm{mg} \mathrm{ml}^{-1}$ hygromycin B (Calbiochem, La Jolla, CA) and plates incubated at room temperature. Hygromycin-resistant colonies appeared after 3 to 5 days of incubation in which the protoplasts had been transformed with pOHT alone or with the mixture of the two plasmids. Hygromycin-resistant colonies were not obtained in transformation with pCU-1 alone or in the absence of transforming DNA.

Two hygromycin-resistant colonies (I1 and I2) obtained by transformation with pOHT alone and 50 randomly chosen colonies obtained by co-transformation of pOHT and pCU-1 were subjected to two cycles of single-spore culture before further analyses. In all these colonies the presence of the hygromycin resistance cassette was confirmed by PCR with primers hph-for (5'CATGGATGCGATCGCTGCG3') and trpCrev (5'AGGTACCGTCTAGAAAGAAGGATTACCTC3').

In order to check for the presence of the $c u$ gene we performed a PCR with primers CU3 (5' GAAGAACATGACTA TACACCA 3') and CU4 (5'AACTTCCACAGTCATGGGC3'), which were designed to match the regions of the $c u$ gene of $O$. novo-ulmi displaying less homology with the $c u$ gene of $O$. $u l m i$ and $O$. himal-ulmi on the basis of the alignments reported by Pipe et al. (1997).

\section{DNA isolation.}

DNA for PCRs was prepared as follows. Blastoconidia were collected from 3-ml cultures grown for 3 days at $28^{\circ} \mathrm{C}$ with agitation, resuspended in $200 \mu \mathrm{l}$ of extraction buffer $(100 \mathrm{mM}$ $\mathrm{NaCl}, 10 \mathrm{mM}$ Tris-HCl pH8.0, $1 \mathrm{mM}$ EDTA, $1 \%$ [wt/vol] sodium dodecyl sulfate [SDS] and 2\% [vol/vol] Triton X-100) and transferred to 1.5-ml Eppendorf tubes. Thereafter, $200 \mu \mathrm{l}$ of a mixture of phenol, chloroform, and isoamylalcohol (25:24:1) and $300 \mathrm{mg}$ of $0.45-\mathrm{mm}$, acid-washed glass beads (Sigma, St. Louis, MO) were added. The tube was vortexed for $2 \mathrm{~min}$, then centrifuged for $5 \mathrm{~min}$ at $12,000 \times \mathrm{g}$. The supernatant was treated with 0.1 volumes of $3 \mathrm{M}$ sodium acetate $\mathrm{pH} 5.5$ and 2 volumes of ethanol, incubated for $10 \mathrm{~min}$ at $-20^{\circ} \mathrm{C}$, and centrifuged for 5 $\min$ at $14,000 \times g$. The pellet was then washed with $70 \%$ ( $\mathrm{vol} / \mathrm{vol}$ ) ethanol and redissolved in $50 \mu \mathrm{l}$ of TE (Tris-EDTA) buffer containing $2 \mathrm{mg} \mathrm{ml}^{-1}$ RNase A (Sigma). One microliter of this DNA preparation was used for each PCR.

For preparation of DNA for Southern blot analysis, cells harvested from a 500-ml liquid shaken culture, grown for 3 days at $28^{\circ} \mathrm{C}$ with agitation were collected by centrifugation at $12,000 \times \mathrm{g}$ for $15 \mathrm{~min}$ at $4^{\circ} \mathrm{C}$, instantly frozen in liquid nitrogen, and freeze dried. DNA was extracted from ground mycelium according to Raeder and Broda (1985).

\section{DNA gel blot analysis.}

Samples $(10 \mu \mathrm{g})$ of genomic DNA were enzyme digested and loaded on a $0.7 \%$ agarose gel in TAE buffer (Sambrook et al. 1989). After electrophoresis $(40 \mathrm{~V}, 4 \mathrm{~h})$ the gel was blotted on Nytran $13 \mathrm{~N}$ nylon membrane $(0.45-\mu \mathrm{m}$ pore size; Schleicher and Schuell, Dassel, Germany) for $1 \mathrm{~h}$ with a model 785 vacuum blotter (Bio-Rad, Hercules, CA) according to the manufacturer's instructions. After DNA fixation with UV, the membrane was probed with a digoxigenin-labeled, 0.55-kb Pst I fragment from pCU-1, containing part of the promoter region and part of the coding sequence of the $c u$ gene of O. novo-ulmi MH75. This fragment was chosen because of its moderate sequence homology with the corresponding region of the $\mathrm{cu}$-homolog of O. quercus (G. Del Sorbo, unpublished data). This reduces the occurrence of cross-hybridization with the endogenous $\mathrm{cu}$-homolog present in the recipient strain. The DNA labeling and detection kit of Boehringer Mannheim (Mannheim, Germany) was used for labeling the probe. The membrane was hybridized overnight at $65^{\circ} \mathrm{C}$ in $20 \mathrm{ml}$ of standard hybridization buffer made of $5 \times$ SSC ( $1 \times \mathrm{SSC}$ is $0.15 \mathrm{M} \mathrm{NaCl}$ plus $0.015 \mathrm{M}$ sodium citrate), $0.1 \%$ (wt/vol) N-lauroylsarcosine, $0.02 \%$ (wt/vol) SDS, and $1 \%$ (wt/vol) blocking reagent (Boehringer Mannheim), and containing $15 \mathrm{ng} \mathrm{ml}^{-1}$ of labeled probe. The membrane was washed at $65^{\circ} \mathrm{C}$ in $0.5 \times \mathrm{SSC} 0.1 \% \mathrm{SDS}$ (wt/vol). The detection procedure was performed with an anti-digoxigenin antibody linked to alkaline phosphatase, and the chemiluminescent phosphatase substrate CDP Star (Boehringer Mannheim). Experiments were repeated with different preparations of DNA.

\section{RNA extraction and gel blot analysis.}

Total RNA was extracted according to Logemann et al. (1987) from freeze-dried mycelia. Northern analysis was performed on samples of $20 \mu \mathrm{g}$ of total RNA electrophoresed on a $1.5 \%$ (wt/vol) agarose gel with the same probe and hybridization buffer described for Southern analysis. Labeling of the probe (0.55-kb PstI fragment from pCU-1), hybridization temperature, post-hybridization washes, and detection of the hybridization signal were performed as described for Southern blot analysis. To check for equal loading the blot was stripped by incubating for $30 \mathrm{~min}$ in stripping buffer made of $50 \%$ (vol/vol) formamide, $50 \mathrm{mM}$ Tris- $\mathrm{HCl} \mathrm{pH} \mathrm{7.5,} \mathrm{and} 1 \%$ (wt/vol) SDS, and the membrane was re-probed with a $0.7-\mathrm{kb}$ fragment obtained by PCR amplification of the region corresponding to the nucleotides 799 to 1557 of the sequence of the actin-encoding gene BcactA of B. cinerea (EMBL accession no. AJ000335).

\section{Determination of $\mathrm{CU}$ production in culture filtrates, in mycelial and leaf extracts.}

Production of $\mathrm{CU}$ in culture filtrates of transformants and reference isolates was determined by the turbidimetric method described by Takai and Richards (1978) as refined by Scala et al. (1994), with microtiter plates, and expressed as the ceratoulmin production index (c.p.i.). To calculate the c.p.i., the turbidity of each sample at various dilutions was measured as optical density at $400 \mathrm{~nm}$. Since a linear relationship between the optical density $(y)$ and the decimal logarithm of the dilution factor $(x)$ occurs for values of $y$ ranging between 0.1 and $2.0(y=\mathrm{a}+\mathrm{b} x)$, the theoretical dilution factor, with $y=1$, is obtained from the development of the power $10^{(1-a) / b}$. The c.p.i. is obtained by multiplying by 100 the dilution factor calculated as above (Scala et al. 1994). The CU production of each isolate was determined on samples collected from three 
independent flasks. Each determination was performed in triplicate wells.

The determination of CU content in freeze-dried, mycelial extracts was determined by ELISA according to the procedure described in Scala et al. (1997b), with an anti-CU antiserum raised in rabbit against purified $\mathrm{CU}$ from culture filtrates of $O$. novo-ulmi (Scala et al. 1994). The presence of CU in elm leaves was determined by ELISA on extracts as described in Scala et al. (1997a).

\section{Plant inoculation, symptom evaluation, and reisolation.}

Pathogenicity field trials were conducted at the Antella Plant Nursery, Florence, Italy. Three-year- old plants of the elm clone Commelin 274 (a hybrid Ulmus glabra $\times$ Ulmus carpinifolia), whose height varied from 2.0 to $2.5 \mathrm{~m}$ were inoculated at about $1.4 \mathrm{~m}$ above ground level on 20 May 1998. On each tree, a cut was made in the sapwood of the main stem with a sterile scalpel blade followed by the application of 150 $\mu \mathrm{l}$ of a suspension containing $10^{8}$ blastoconidia $\mathrm{ml}^{-1}$ by the method described by Scala et al. (1997a). Before inoculation, blastoconidia were washed three times with water to eliminate residual CU present in culture filtrate. Each Ophiostoma wildtype or transformant strain was inoculated on five plants. The trees immediately absorbed the suspensions and the wounds were then sealed with tape. Disease symptoms, including determination of percentage of foliar symptoms (chlorosis, wilting, and defoliation), as well as vascular discoloration length and discoloration intensity were assessed 28 days after inoculation. For determination of the percentage of positive reisolation from both symptomatic and asymptomatic plants, 2-cm-thick stem cylinders were collected from each plant 28 days after inoculation at the inoculation site as well as $0.6 \mathrm{~m}$ above and below it. From each cylinder, 20 fragments of xylematic and adjacent tissues were aseptically removed underneath the cortex and placed on MEA containing $0.1 \mathrm{mg} \mathrm{ml}^{-1}$ cycloheximide and $1 \mathrm{mg} \mathrm{ml}^{-1}$ streptomycin sulfate (Brasier 1981). Reisolated mycelia were transferred onto MEA containing $0.1 \mathrm{mg} \mathrm{ml}^{-1}$ hygromycin B to check for the stability of the hygromycin-resistant phenotype. To confirm the identity of reisolated fungi, DNA was extracted from reisolated mycelial samples (three samples per transformant) and subjected to Southern and RAPD analysis, along with samples of DNA extracted from cultures used for plant inoculation. For RAPD analysis, $5 \mathrm{ng}$ of DNA and $0.3 \mu \mathrm{M}$ primer 220 (5'CAGCAC $\mathrm{CCAC}^{\prime}$ ) was used in $1 \times$ PCR buffer (Boehringer Mannheim) in the presence of $2.5 \mathrm{mM} \mathrm{MgCl}_{2}$ and $200 \mu \mathrm{M} \mathrm{dNTP}$ (Boehringer Mannheim). Amplification conditions of the thermocycler (Perkin-Elmer Cetus, Foster City, CA) were one cycle for $2 \mathrm{~min}$ at $94^{\circ} \mathrm{C}$ followed by 35 cycles of $30 \mathrm{~s}$ at $94^{\circ} \mathrm{C}$, $45 \mathrm{~s}$ at $40^{\circ} \mathrm{C}$, and $3 \mathrm{~min}$ at $72^{\circ} \mathrm{C}$. The final cycle was $7 \mathrm{~min}$ at $72^{\circ} \mathrm{C}$. To minimize environmental risks, a 30-m-wide, vegetation-free zone was created around inoculated plants. After the trial all trees and/or plant residues were removed and destroyed, and the soil sterilized with Dazomet (Solplant, Milan, Italy).

\section{Analysis of stability of $\mathrm{CU}$ production in $O$. quercus transformants.}

To study the stability of the hygromycin-resistant phenotype and the ability to produce $\mathrm{CU}$, primary transformants were subjected to four subsequent transfers on plates of solid Takai medium lacking the antibiotic. Thereafter, small mycelial plugs $\left(2 \mathrm{~mm}^{3}\right)$ were plated on the same medium containing hygromycin, or used for inoculation of liquid cultures of Takai medium, which were incubated at $23^{\circ} \mathrm{C}$ for 7 days on a rotary shaker. The culture filtrate was used for determination of the c.p.i.

\section{ACKNOWLEDGMENTS}

We thank Bianca Del Monte for growing the Ophiostoma isolates and for cerato-ulmin determination in culture filtrates and mycelial extracts. We gratefully acknowledge P. A. Horgen (Department of Botany, University of Toronto, Mississauga, Ontario, Canada) and C. M. Brasier (Forest Research Station, Alice Holt Lodge, Farnham, Surrey, U.K.) for providing the plasmid $\mathrm{pCU}-1$ and the $O$. quercus recipient isolate $\mathrm{H} 988$, respectively. L. Mittempergher (Istituto per la Patologia degli Alberi Forestali, CNR, Firenze, Italy) kindly provided elm plants. G. P. was supported by a post-doctoral fellowship from the Università degli Studi di Firenze. This research was supported by grants from MURST (ex $40 \%$ ) to A. S. and F. S., and by a grant from CNR, strategic project "Biodiversità," contract no. 98.03481ST76, to F. S.

\section{LITERATURE CITED}

Bowden, C. G., Hintz, W. E., Jeng, R., Hubbes, M., and Horgen P. A. 1994. Isolation and characterization of the cerato-ulmin toxin gene of the Dutch elm disease pathogen, Ophiostoma ulmi. Curr. Genet. 25: 323-329.

Bowden, C. G., Smalley, E., Guries, R. P., Hubbes, M., Temple, B., and Horghen, P. A. 1996. Lack of association between cerato-ulmin production and virulence in Ophiostoma novo-ulmi. Mol. Plant-Microbe Interact. 9:556-564.

Brasier C. M. 1981. Laboratory investigations on Ceratocystis ulmi. Pages 76-79 in: Compendium of Elm Diseases. R. J. Stipes and R. J. Campana, eds. American Phytopathological Society, St. Paul, MN.

Brasier, C. M. 1990. China and the origin of Dutch elm disease: An appraisal. Plant Pathol. 39:5-16.

Brasier, C. M. 1991. Ophiostoma novo-ulmi sp. nov., causative agent of current Dutch elm disease pandemics. Mycopathologia 115:151-161.

Brasier, C. M. 1993. The genetic system as a fungal taxonomic tool: Gene flow, molecular variation and sibling species in the "Ophiostoma piceae-Ophiostoma ulmi" complex and its taxonomic and ecological significance. Pages 77-93 in: Ceratocystis and Ophiostoma, Taxonomy, Ecology and Pathogenicity. M. J. Wingfield, K. A. Seifert, and J. F. Webber, eds. American Phytopathological Society, St. Paul, MN.

Brasier, C. M. 1995. Episodic selection as a force in fungal microevolution, with special reference to clonal speciation and hybrid introgression. Can. J. Bot. 73:S1213-1221.

Brasier, C. M., and Kirk, S. A. 1989. European oak decline. Status of $O$. piceae on hardwood and conifers. Rep. For. Res. HMSO London 1989:47-48.

Brasier, C. M., Kirk, S. A., and Tegli, S. 1995. Naturally occurring non cerato-ulmin producing mutants of Ophiostoma novo-ulmi are pathogenic but lack aerial mycelium. Mycol. Res. 99:436-440.

Brasier, C. M., and Stephens, T. M. 1993. Temperature-growth responses distinguish the OPC and OPH sibling species within Ophiostoma piceae. Mycol. Res. 97:1416-1418.

Brasier, C. M., Takai, S., Nordin, J. H., and Richards, W. C. 1990. Differences in cerato-ulmin production between the EAN, NAN and nonaggressive subgroups of Ophiostoma ulmi. Plant Pathol. 39:231-236.

Charter, N. W., Buck, K. W., and Brasier, C. M. 1996. Multiple insertions and deletions determine the size differences between the mitochondrial DNAs of the EAN and NAN races of Ophiostoma novoulmi. Mycol. Res. 100:368-378.

Et-Touil, A., Brasier, C. M., and Bernier, L. 1999. Localization of a pathogenicity gene in Ophiostoma novo-ulmi and evidence that it may be introgressed from O. ulmi. Mol. Plant-Microbe Interact. 12:6-15.

Georgescu, C. C., Teodoru, I., and Badea, M. 1948. Uscarea in massa a stjarului. Anal. Inst. Cerc. For. Rom. 11:185-223.

Georgevitch, M. P. 1926. Ceratostomella quercus n.sp. Acad. Sci. C. R. Paris 183:759. 
Hausner, G., Reid, J., and Klassen, G. R. 1993. On the phylogeny of Ophiostoma, Ceratocystis s.s. and Microascus and relationships within Ophiostoma based on partial ribosomal DNA sequences. Can. J. Bot. 71:1249-1265.

Kershaw, M. J., and Talbot, N. J. 1997. Hydrophobins and repellents: proteins with fundamental roles in fungal morphogenesis. Fungal Genet. Biol. 23:18-33.

Logemann, J., Schell, J., and Willmitzer, L. 1987. Improved method for the isolation of RNA from plant tissues. Anal. Biochem. 163:16-20.

Mellon, F. M., and Casselton, L. A. 1988. Transformation as a method to increase gene copy number and gene expression in the basidiomycete fungus Coprinus cinereus. Curr. Genet. 14:451-456.

Pipe, N. D., Buck, K. W., and Brasier, C. M. 1995. Genomic fingerprinting supports the separation of Ophiostoma piceae into two species. Mycol. Res. 99:1182-1186.

Pipe, N. D., Buck, K. W., and Brasier, C. M. 1997. Comparison of the cerato-ulmin $(\mathrm{cu})$ gene sequences of the Himalayan Dutch elm disease fungus Ophiostoma himal-ulmi with those of $O$. ulmi and $O$. novo-ulmi suggests that the $c u$ gene of $O$. novo-ulmi is unlikely to have been acquired recently from $O$. himal-ulmi. Mycol. Res. 101: 415-421.

Raeder, U., and Broda, P. 1985. Rapid preparation of DNA from filamentous fungi. Lett. Appl. Microbiol. 1:17-20.

Richards, W. C. 1993. Cerato-ulmin: A unique wilt toxin of instrumental significance in the development of Dutch elm disease. Pages 89-151 in: Dutch Elm Disease Research: Cellular and Molecular Approaches. M. B. Sticklen and J. L. Sherald, eds. Springer Verlag, New York.

Royer, J. C., Dewar, K., Hubbes, M., and Horgen, P. A. 1991. Analysis of a high frequency transformation system for Ophiostoma ulmi, the causal agent of Dutch elm disease. Mol. Gen. Genet. 225:168-176.

Sambrook, J., Fritsch, E. F., and Maniatis, T. A. 1989. Molecular Cloning: A Laboratory Manual. 2nd ed. Cold Spring Harbor Laboratory, Cold Spring Harbor, NY.

Scala, A., Pattuelli, M., Coppola, L., Guastini, M., Tegli, S., Del Sorbo, G., Mittempergher, L., and Scala, F. 1997a. Dutch elm disease progression and quantitative determination of cerato-ulmin in leaves, stems and branches of elms inoculated with Ophiostoma novo-ulmi and $O$. ulmi. Physiol. Mol. Plant Pathol. 50:349-360.

Scala, A., Tegli, S., Comparini, C., Mittempergher, L., Scala, F., and Del Sorbo, G. 1994. Influence of fungal inoculum on cerato-ulmin production: Purification of cerato-ulmin and detection in elm sucker cuttings. Petria 4:53-63.

Scala, F., Bertelli, E., Coppola, L., Del Sorbo, G., Tegli, S., and Scala,
A. 1997b. Comparative determination of cerato-ulmin on cell surface and in mycelial extracts of pathogenic and non-pathogenic Ophiostoma species. Mycol. Res. 101:829-834.

Smalley, E. B., and Guries, R. P. 1993. Breeding elms for resistance to Dutch elm disease. Annu. Rev. Phytopathol. 31:325-352.

Stringer, M. A., and Timberlake, W. E. 1993. Cerato-ulmin, a toxin involved in the Dutch elm disease, is a fungal hydrophobin. Plant Cell 5:145-146.

Sutherland, M. L., Mittempergher, L., and Brasier, C. M. 1995. Control of Dutch elm disease by induced host resistance. Eur. J. For. Pathol. 25:307-318.

Sutherland, M. L., Pearson, S., and Brasier, C. M. 1997. The influence of temperature and light on defoliation levels of elm by Dutch elm disease. Phytopathology 87:576-581.

Takai, S. 1974. Pathogenicity and cerato-ulmin production in Ceratocystis ulmi. Nature 252:124-126.

Takai, S. 1978. Cerato-ulmin, a wilting toxin of Ceratocystis ulmi: Cultural factors affecting cerato-ulmin production by the fungus. Phytopathol. Z. 91:147-158.

Takai, S. 1980. Relationship of the production of the toxin, ceratoulmin, to synnemata formation, pathogenicity, mycelial habit, and growth of Ceratocystis ulmi isolates. Can. J. Bot. 58:658-662.

Takai, S., and Hiratsuka, Y. 1984. Accumulation of the material containing the toxin cerato-ulmin on the hyphal surface of Ceratocystis ulmi. Can. J. Bot. 58:663-668.

Takai, S., and Richards, W. C. 1978. Cerato-ulmin, a wilting toxin of Ceratocystis ulmi: Isolation and some properties of cerato-ulmin from the culture of C. ulmi. Phytopathol. Z. 91:129-146.

Tegli, S., Comparini, C., Giannetti, C., and Scala, A. 1994. Effect of temperature on growth and cerato-ulmin production of Ophiostoma novo-ulmi and Ophiostoma ulmi. Mycol. Res. 97:408-412.

Tegli, S., and Scala, A. 1996. Isolation and characterization of non cerato-ulmin producing laboratory induced mutants of Ophiostoma novo-ulmi. Mycol. Res. 100:661-668.

Temple, B., Horgen, P. A., Bernier, L., and Hintz, W. E. 1997. Ceratoulmin, a hydrophobin secreted by the causal agents of Dutch elm disease, is a parasitic fitness factor. Fungal Genet. Biol. 22:39-53.

ten Have, A., Mulder, W., Visser, J., and van Kan, J. A. L. 1998. The endopolygalacturonase gene Bcpg1 is required for full virulence of Botrytis cinerea. Mol. Plant-Microbe Interact. 11:1009-1016.

Wu, W. D., Jeng, R. S., and Hubbes, M. 1989. Toxic effects of elm phytoalexin mansonones on Ophiostoma ulmi, the causal agent of Dutch elm disease. Eur. J. For. Pathol. 19:343-357. 